\title{
Bedřich Smetana's Deafness
}

\section{Jan Betka}

The cause of Bedrrich Smetana's deafness has been discussed many times. Numerous theories about the aetiology of his deafness have been expressed, but only recent research has offered more definite answers. The aim of this paper is to describe the development of Bedrrich Smetana's hearing problems and their cure, to point out the results of autopsy, and to present the findings resulting from examination of the composer's remains.

There is no information on Smetana's ancestors suffering ear illnesses. The composer was a passionate hunter, and, in his childhood, was deafened by an explosion of a bottle filled with gun powder. None of this, however, lead to his later deafness. In April 1874, Smetana marked in his diary, that he "suffered from a boil". ${ }^{1}$ This boil was healing for eighteen days; no closer information of its place is known. In the beginning of May 1874, Smetana marked in his notebook the beginning of some throat problems, which he described as throat pains, noting "tonsilitis". ${ }^{2}$ In July 1874, Smetana mentioned a rash; on July 28th, 1874 (the information on the date varies), he noted hearing problems for the first time. He went to Prague to find medical help, where he visited the famous ear specialist Emannuel Zaufal, who was an Adjunct Professor at the German Ear Clinic of Karl-Ferdinand University. To Zaufal, the composer complained of intensive vertigo, tinnitus and disturbed hearing. He was diagnosed as suffering from an illness of the Eustachian tube. The cure was on the level of period medicine - it consisted of air douches (blowing air into the middle ear via the Eustachian tube). Smetana was probably in great discomfort, because he was even ready to give up his favourite hunting. The ear problems were so intensive and disturbing, that in September 1874, he had to give up his Kapellmeister post. He continued his visits to Professor Zaufal, who tried to make his patient's problems better by ear airing. At first, Smetana lost the hearing in his right ear; the hearing deficiency of his left ear oscillated, and, temporarily, perhaps even improved. On October 20th, 1874, however, Smetana noted that his illness had worsened to such an

\footnotetext{
${ }^{1}$ H. Feldmann, "Die Krankheit Friedrich Smetanas in otologischer Sicht auf Grund neuer Quellenstudien”, Monatsschrift für Ohrenheilkunde und Laryngo-Rhinologie 98, Heft 5 (1964): 209-226 (the English version was published in: The Music Review 32 (1971): 233-247).

${ }^{2}$ Ibid.
} 
extent that he did not hear either in his left or right ear. Professor Zaufal changed the cure, suggesting absolute rest in isolation, the patient's ears were covered by cotton wool, soaked in oil, and he was allowed visits only by the doctor and a maid-servant. Smetana started fearing the worst, and, on October 30th, 1874, noted: "I fear the worst, [...]. [...] I cannot hear anything. [...] What if I would not heal at all!"3 During November and December 1874, despite the continuing cure, Smetana started losing hope. Apart from deafness in both ears, his main problem became the "buzzing". The specialists call this state tinnitus; for Smetana, it was subjective tinnitus, by which sound is heard only by the patient. He decided to get another specialist opinion. In April 1875, he visited one of probably the most famous ear specialists, Professor A. F. von Trölsch, to whom he travelled to Würzburg, and who gave him a five day cure. Von Trölsch agreed with Zaufal's suggestions, and advised Smetana "to get his eardrums opened". In May of the same year, Smetana visited the famous Professor Adam Politzer in Vienna, who decided that his labyrinth was paralysed, and advised electric stimulation and using a hearing aid. After he returned home, Smetana started a cure, during which ointment was applied behind his ears, and he remained in total silence. The ointment cure continued up to June 1875, but it did not bring any improvement. In July 1875, Smetana consulted Dr. Pospíšil, but the type of cure he suggested is not clear. He also visited Dr. Hagen in Leipzig, who suggested the patient be "stimulated by electricity". This cure started in October 1875, again under Zaufal's supervision. It consisted of inserting electrodes into both external ducts and electric stimulation, which should have influenced the tinnitus. Smetana, however, did not describe any improvement. In July 1875, he moved to his daughter $\check{Z}$ ofie, in the Jabkenice hunting lodge. He came to terms with his deafness; the worst of all for him was the tinnitus. He wrote: "The humming, the roar, that is the worst suffering of all. The deafness would be a relatively good state, would there be silence in my head. But the worst torture for me is the almost incessant inner noise, the humming in my head, and, sometimes, escalating to a stormy roll." ${ }^{4}$ In the following years, Smetana gave up further cure experiments, and the main symptom became the disturbing tinnitus. The vertigo ceased, and he was still deaf in both ears. In 1882, symptoms of psychiatric disease began to appear; on May 12th, 1884, Smetana died in the Institute for Psychiatric Patients in Prague.

\footnotetext{
${ }^{3}$ Quoted from Emanuel Vlček, Bedřich Smetana fyzická osobnost a hluchota [Bedřich Smetana's Physiognomy and Deafness] (Prague: Vesmír, 2001), 50.

${ }^{4}$ Eliška Pechová-Krásnohorská, “Ze vzpomínek na Bedřicha Smetanu” [Remembering Bedřich Smetana], in: Co prinesla léta. Drubé knihy vzpominek II [What the Time Brought. Second Book of Memoirs, II] (Prague: Vaněk a Votava, 1928), 25.
} 


\section{ZTRÁTA SLUCHU U BEDR̈ICHA SMETANY (rekonstrukce chorobopisu)}

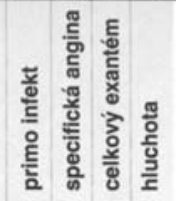

1874

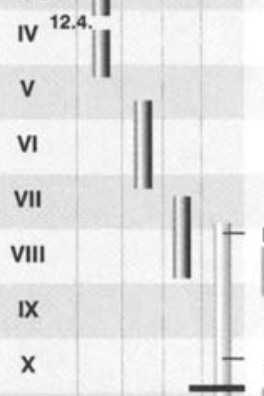

$\mathbf{X I}$

XII

1875

II

III

III

IV

V

VI

VII

VIII

IX

$\mathrm{X}$

X

XI

XII léčeni

korespondence

27. 3. premiéra

Dvou vdov

sluchové potižze

prof. Zaufal (Tubenkatar) (Praha)

Luftinhalation

II Luftduschen

katetrizace tub

zlepšeni vlevo

absolutní šetřeni sluchu

(vata v ušich, klid doma,

revize dg. + zmèna terapie)

úplné ohluchnutí

15. 8. vzdal se kapelnictvi

(Dalibor 15. 8. 1974)

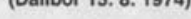

26. 2. dopis L. Quise

vyśețiení u prof. von Tröltsche (Würzburg),

dg. katar nebyl ještě pinẻ opuštèn, doporučeno otevréní bubínkủ

vyšetření u prof. Politzera (Vídeñ), dg. zánèt labyrintu, 22. 5. dopis

24.5 doporučena elektrizace, sluchová cvičení dceři Żofii

prof. Zaufal (Praha), dg. onemocnéni sluchového nervu

Schmierkur (mast $\mathrm{Hg}$ ), absolutní klid doma, uši ucpat, s nikým nemluvit, odstranit hluk, sluchová cvičení

24. 7. dopis K. Bendlovi

3. 9. 1975 obrovský nežit pod ramenem (cibulové obklady)

23. 9.1975 nežit v podpaždí

\section{zahájeni elektrizace}

levým uchem zaslechl vêtu (=zlepšeni???)

elektrizace provedena již $25 x$
Smetanúv

denik

30. 4. 74

11. 6. 74

28. 6.74

14. 7.74

28. 7.74

1. 8.74

8. 8.74

3. 9.74

15. 9.74

4. 10.74

28. 18.74

30. 10.74

1. 11.74

30. 11.74

20.-25. 4. 75

5. 5. 75

24. 5.75

25. 10. 75

28. 10.75

orig. E. Vlcek, 1984

Picture 1: Bedřich Smetana's loss of hearing - a reconstruction of the clinical history of Bedrich Smetana's deafness. 
The autopsy was performed by the Professor of Pathological Anatomy, Associate Professor Jaroslav Hlava MD, in the Hlava Institute in Prague. The autopsy protocol shows a long time existing progressive paralysis; already, syphilis was suggested. ${ }^{5}$

In 1988, Prof. Karel Sedláček examined the right petrous bone, taken out during the autopsy. No signs of inflammation, which would have damaged the bone structure, were found, not even on the edges of the oval window. From this finding, the cause of the sudden deafness was impossible to state. The auditory ossicles were examined by

Alena Němečková. Both right side ossicles were well preserved. Changes were found on both ossicles (malleus and incus), typical for paleopathological bone tissues. The ossicles were examined, magnified $1500-2500$ times. The conclusion was that the ossicles were affected by inflammation, which moved from the mucosa to the bone. A CT examination was performed on the temporal bone, where neither an anatomic anomaly nor distinct pathologic change of the cochlear labyrinth were found; reduction of the number of coils, ossification of the cochlea or major pathological changes of the inner ear were ruled out. The examination also excluded the possibility of serious chronic inflammation of the mastoid process of the right temporal bone. Two different methods of serological examination, convincingly proved the existence of a positive reaction to the antibodies against Treponema pallidum. Today, it is possible to state explicitly, that Bedřich Smetana suffered of an infectious disease, syphilis. The most probable time of onset of the illness should be considered as the year 1874, when Smetana described the individual stages of this illness, as well as the parallel start of hearing problems, which, in October of that year, lead to the definitive loss of hearing. The infection was transferred to the inner ear by the blood; consequently, the illness damaged the inner ear vestibular system, destroyed the hearing organs, and led to the development of subjective tinnitus. Other pathological processes were also named as causes of the deafness; ${ }^{6}$ in the light of recent information and examinations performed after the composer's body was exhumed, all the other theories totally lose their credibility.

\footnotetext{
${ }^{5}$ Ladislav Haškovec, “O Hlavovu diagnosu choroby Smetany” [Hlava's Diagnosis of Smetana's Illness], Revue v neurologii a psychiatrii [The Neurology and Psychiatry Revue] 22, nos. 7-8 (1925): 211-233. Ladislav Haškovec, O Hlavovu diagnosu choroby Smetany, Z ambulatoria pro choroby nervové [Hlava's Diagnose of Smetana's Illness. From the Nerve Disease Outpatient Clinic], published at the author's own expense (Třeboň, 1925).

${ }^{6} \mathrm{H}$. Šikl, "Ke sporu o chorobu Bedřicha Smetany" [On the Dispute of Bedřich Smetana's Illness], $\check{C} L \check{C}$ [Český lékařský časopis] 64, no. 21 (1925): 840. Ibid., "Pitevní protocol (faksimile)" [Facsimile of the Autopsy Protocol], ibid., after p. 840.
} 
Conclusion: Bedřich Smetana, the genial Czech composer, at the age of 50, lost his hearing in consequence of the onset of venereal disease - syphilis, caused by Treponema pallidum. The infection was transported by blood to the inner ear, which the infection destroyed, and caused the patient's double-sided deafness, and consequent tinnitus. Despite all the hardship which Smetana had to suffer, this horrible illness did not influence his creative spirit. It is difficult to believe that even by these, for a composer, difficult conditions, he was still able to write high quality compositions. He remains a model of a man, who, even if tormented by his destiny, remained a genius.

Translated by Michaela and David Freeman; revised by Cyril Šálek
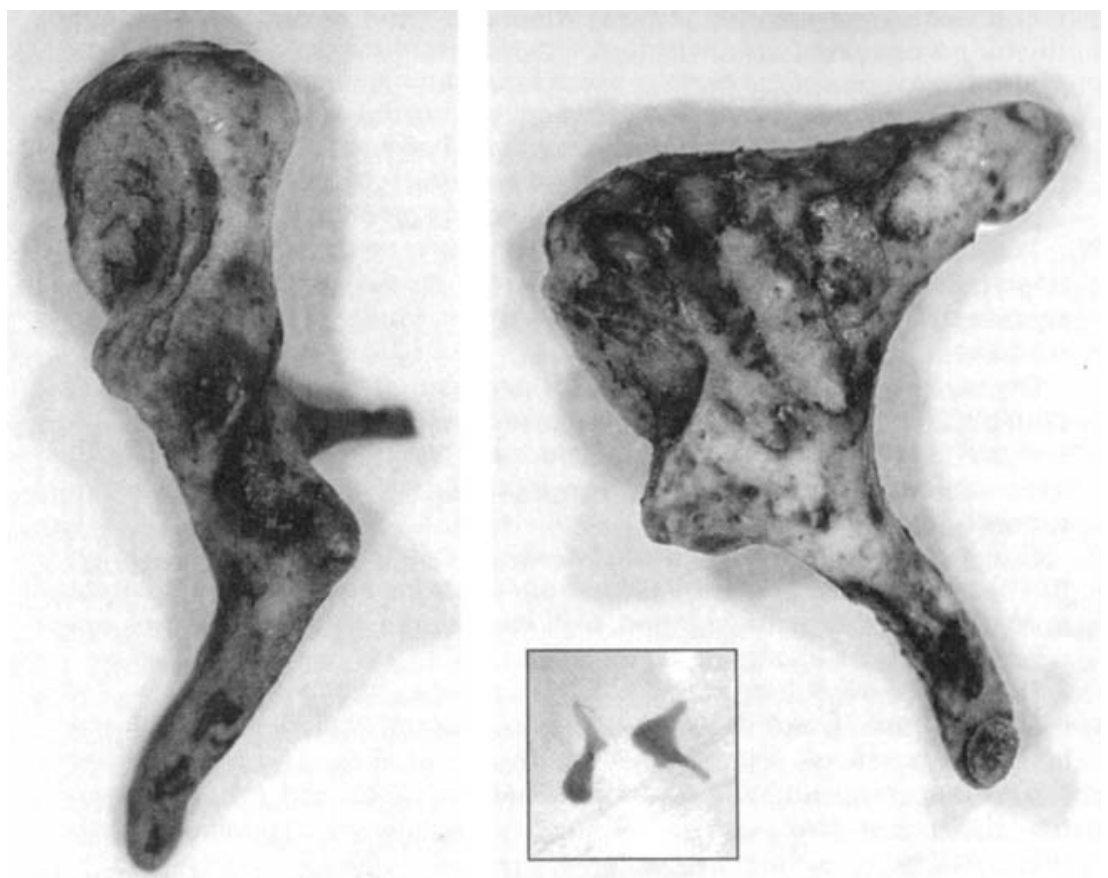

Picture 2: Smetana's surviving ossicles and their X-ray. 


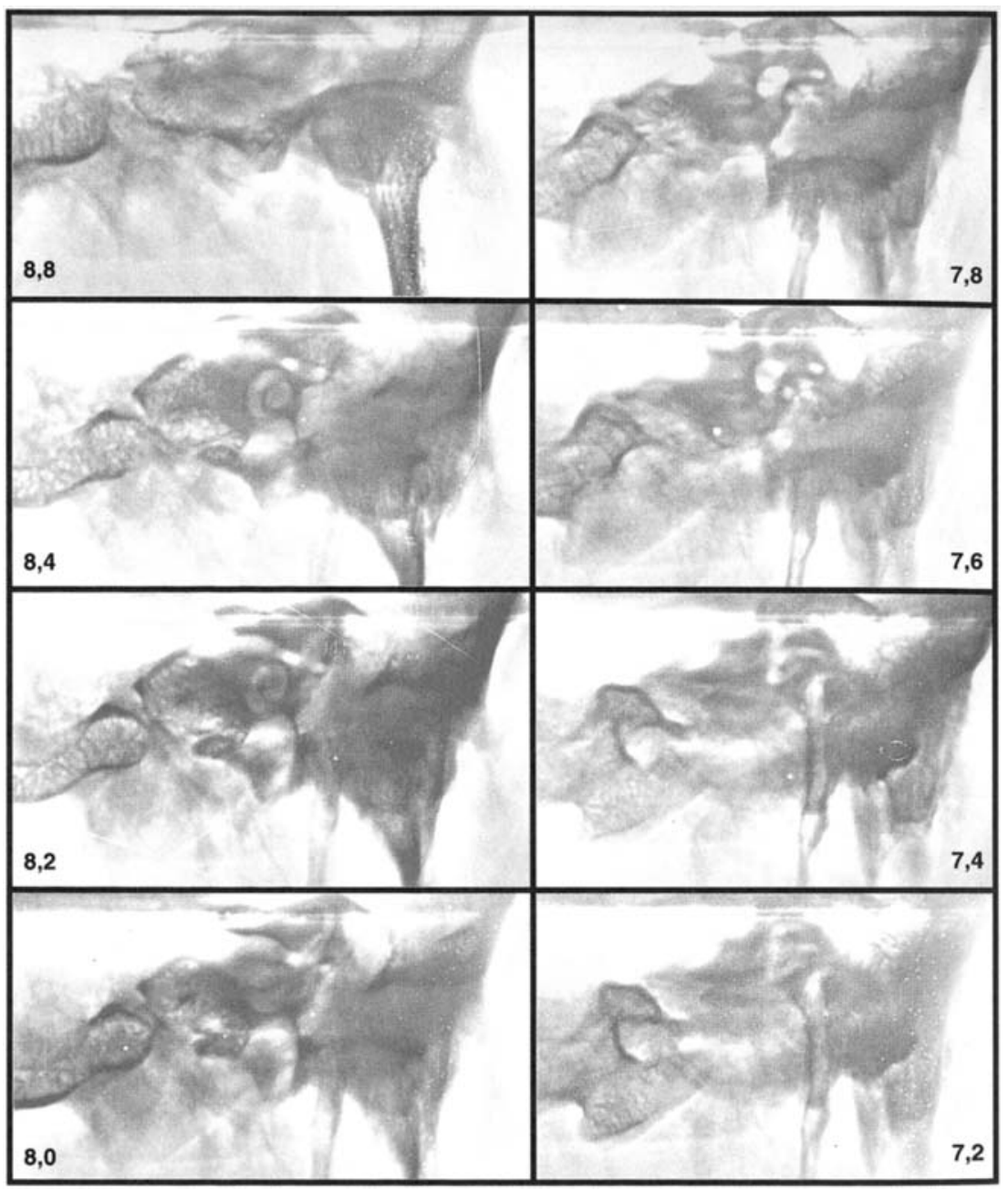

Picture 3: CT scans of the right temporal bone. No anatomic anomalies of the bone or serious inflammatory changes of the mastoid process were found. 


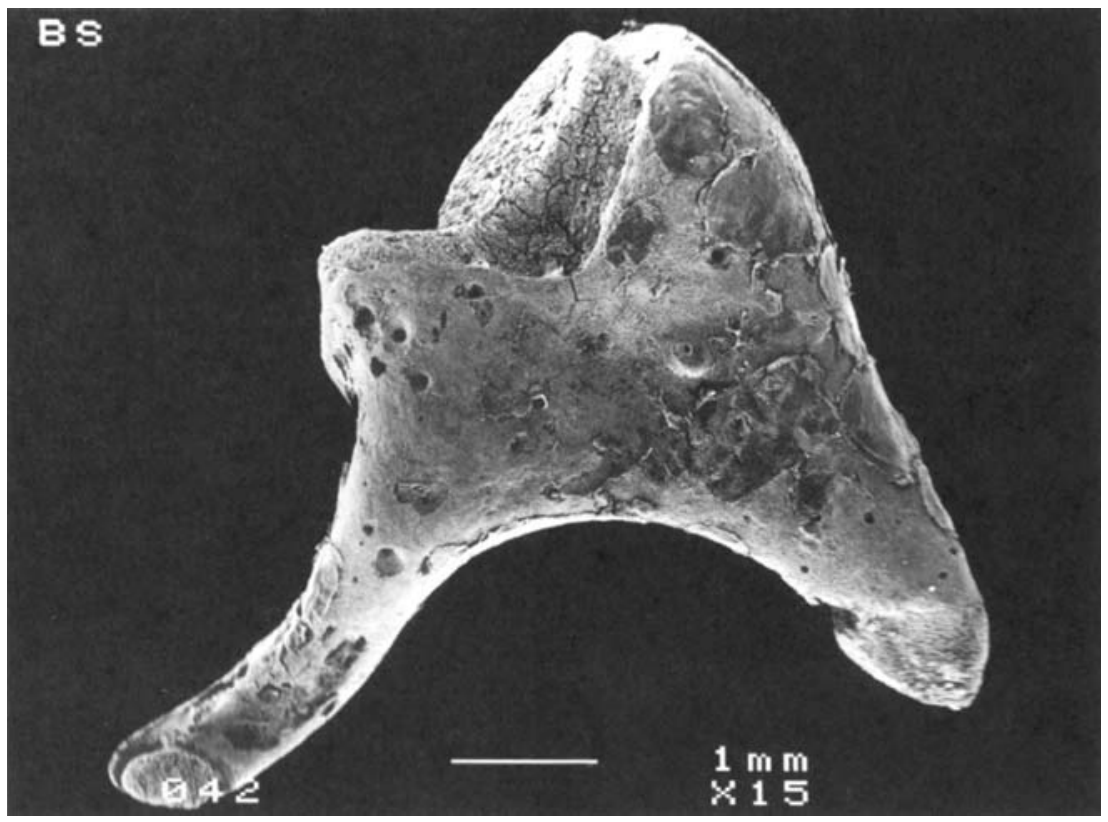

Picture 4: Full view of the incus with the surviving area on which the head of the malleus would lie.

\section{Bedřich Smetana's Deafness}

\section{Abstract}

The study reconstructs the sequence of events leading to B. Smetana's deafness. It re-examines the autopsy report and analyses the preserved bones of Smetana's middle ear for the possibility of an infectious disease. The study considers the maximum number of factors, including the exceptional surge in creative activity in the last decade of Smetana's life, in order to draw a definite conclusion in the form of a medical image - deafness as a consequence of a veneric infection.

\section{Hluchota Bedřicha Smetany}

\section{Abstrakt}

Studie rekonstruuje sled událostí, které vedly k ohluchnutí B. Smetany. Přezkoumává pitevní zprávu a díky zachovaným kůstkám Smetanova středouší 
analyzuje možnosti infekčního onemocnění. Je zvažováno maximum faktorů, včetně mimořádně vzepnuté tvưrčí aktivity v posledním desetiletí Smetanova života, aby byl konstatován jednoznačný závěr v podobě medicínského obrazu ohluchnutí jako následek venerické nákazy.

\section{Keywords}

Bedřich Smetana; deafness; hearing problems and their cure

\section{Klíčová slova}

Bedřich Smetana; hluchota; problémy sluchu a jejich léčba

Jan Betka

Klinika otorinolaryngologie a chirurgie hlavy a krku 1. LF UK a FN v Motole Záběhlická 3217/63

10600 Praha 10, Česká republika

ordinace@orlbetka.cz 